repair work may be added.

The officials also stress that the success or otherwise of the repair will not be immediately apparent. Alignment and calibration of the equipment installed to improve Hubble's resolution will not be complete for seven weeks, and a full programme of science using the telescope is not expected to resume for 14 weeks.

If an additional shuttle mission is needed to complete the repair, it could take place in between five and thirteen months time, depending on the tasks needed, says Joe Rothenberg, flight projects manager. Officials on Capitol Hill say that Congress would probably approve such a mission in order to rescue the $\$ 3$ billion already invested in Hubble.

But the ramifications of technical problems on next week's mission would be much broader, influencing in particular Congress's perception of NASA's ability to construct the space station, on budget, through a series of shuttle missions. "If this goes wrong it will be very serious", says Washingtonbased space consultant Wilfred Mellors.

Colin Macilwain

\section{Multimedia patent sparks protest}

Washington. A small California company which has won a broad patent covering virtually all types of multimedia computer software is expecting a torrent of litigation from rival companies before it attempts to extract licence fees from them next June.

Thesc companies, as well as several patent lawyers, have attacked the US Patent and Trademark Office for issuing such a broad patent, and called for its procedures to be changed to allow outsiders to comment on patents before they are awarded.

The US patent has been awarded to Compton's NewMedia of Carlsbad, California, and raised both eyebrows and tempers when its existence was revealed at a computer exhibition in San Diego, California, last week. The patent appears to cover almost any type of database capable of storing video and audio information along with computer data.

"Any patent invites some sort of challenge", says Pat Meier, a spokeswoman for the company. "Initially people were infuriated by the announcement, but now they are settling down and asking what it really means."

Compton's NewMedia will seek a three per cent licence fee from rivals after next June, Meier says, although those who make a distribution agreement by then will pay less. The privately owned company has 150 staff, and has pioneered the development and retailing of multimedia, computer-based encyclopaedias over the past ten years. But revenue from the patent may dwarf income from its current activities.

Colin Macilwain

\title{
Plant biologists sow seeds of EU funding experiment
}

Paris. The European Commission may delegate management of much of the European Union (EU)'s proposed ECU13.1 billion (US\$14.8 billion) fourth Framework programme to the scientific community. The decision will depend partly on the outcome of a test case within the EU's third Framework programme, where a consortium led by the John Innes Institute in Norwich (UK) and the Max Planck Institute in Cologne (Germany) will manage an ECU24 million plant molecular biology project.

Technically speaking, the Commission will contract the project to a European Economic Interest Grouping (EEIG) comprising the John Innes and Max Planck institutes only. But the institutes say this is only to simplify legal arrangements, and that the EEIG will delegate power to a board made up of leading scientists from several European countries.

This board, known as AMICA (A Molecular Initiative in Community Agriculture), was formed four years ago. It aimed to persuade the then research commissioner, Filippo Pandolfi, that it should organize, seek proposals for and peer review all Commission research in plant

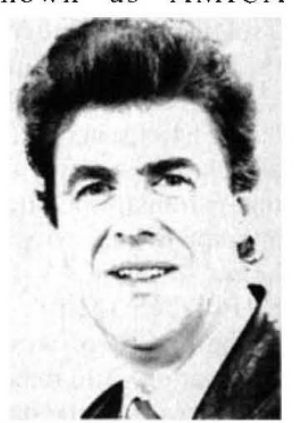

Richard Flavell: "adding value". molecular biology.

Last year, the Commission decided that this could not be done, given its legal responsibility to European taxpayers to decide how money is allocated. But the Commission invited AMICA to submit, as a trial, its own proposal for the EU's Priority Technological Programme (PTP) on Plant Molecular Genetics for an Environmentally Compatible Agriculture.

AMICA subsequently sent out more than 500 applications for peer review, and selected 116 projects. But the Commission's own subsequent peer-review process eliminated half of these. The Commission also funded about 50 applications out of 500 received separately from small independent research consortia.

AMICA's original proposal was dead, but it was subsequently asked to manage the entire PTP. The Commission wanted to test devolved management, not least because a recruitment freeze meant that increases in its scientific staff would not keep pace with the proposed doubling of the EU's research budget in the fourth Framework programme After long negotiations, AMICA-EEIG persuaded the 50 or so independent groups that the Commission had chosen to come under its umbrella. As a result, AMICAEEIG will now coordinate and evaluate all 117 laboratories taking part in the PTP; previously, EU programmes consisted of many small consortia, each linking on average five laboratories, and were managed by commission officials.

Jeff Schell, director of the Max Planck Institute, sees AMICA-EEIG as a model for EU involvement in science. He said that coordinating efforts in national institutions meets the principle of subsidiarity. Richard Flavell, director of the John Innes Institute, says a major aim of the programmes is to use the size and diversity of the participating groups to add value to national and international programme on plant science.

One Commission official says if AMICAEEIG succeeded, similar structures were likely to be set up in other research fields within the fourth Framework programme.

However, some researchers fear that devolved management, which they welcome, could be the first step towards devolution of the power to determine which projects receive EU funding and to shape future programmes.

Jean Dénariér, from the Centre National de la Recherche Scientifique Laboratory in Toulouse (France) criticizes what he describes as the "concentration of power" in AMICA-EEIG, and in particular its initial attempt to select proposals.

Dénariér also argues that putting a few leading scientists in control of all EU-funded work in a particular field will lead to poorer countries being given less. He adds that the European Commission is best placed to provide independent control over who gets funded what. "Community research is not only about funding Europe's best laboratories, but about developing the scientific potential of those countries which lag behind," he says.

Schell agrees that a science-driven system would provide a "selective advantage to those institutions and countries that do a good job in science". But he points out that the Commission had earmarked ECU1.5 million of AMICA-EEIG's programme for training programmes in Greece, Portugal and Ireland. "The jury is still out" on whether poorer countries would accept AMICAEEIG, he says.

One Commission official says the question of delegating control of research programmes to groups of scientists is "not open to discussion". But he admits that it could happen "if there were sufficient safeguards that the ultimate responsibility lay with the Commission".

Declan Butler 